\author{
Agnieszka Marek \\ The John Paul II Catholic University of Lublin \\ Faculty of Social Sciences \\ Department of Employees Management in Organisation \\ e-mail: agnieszka.marek@kul.pl
}

\title{
Corporate social responsibility in FC Barcelona as Carroll's CSR pyramid in practice
}

\begin{abstract}
Corporate social responsibility (CSR) is a subject of great interest to both theoreticians and practitioners of management as well as to international organisations that promote this idea among existing enterprises. Despite many years of research on CSR, there is no single binding definition of this concept, therefore for the needs of this publication, the definition of Archie B. Carroll, and the resulting approach to CSR implementation in companies, has been adopted. The aim of the article is to analyse CSR activities undertaken by FC Barcelona in the framework of a system derived from Carroll's CSR pyramid, therefore its activities have been divided into four groups corresponding to the dimension of financial, legal, ethical and philanthropic responsibilities. Due to the commercialisation of football, FC Barcelona is treated as a global enterprise, considering, however, the specificity of regulations governing the sports sector as well as goods and services offered by the club. The research has been based on an analysis of literature and available documents published by the club itself as well as by international organisations regulating football tournaments on national and international levels. The study has indicated that FC Barcelona is taking action in all the dimensions of social responsibility highlighted in Carroll's pyramid and can be seen as a socially responsible organisation, at the same time meeting expectations of its stakeholders.
\end{abstract}

Keywords: corporate social responsibility, FC Barcelona, Carroll's CSR pyramid

JEL Classification: M14, Z20 


\section{Introduction}

Under the influence of changes taking place in the economy, football clubs have changed their character from local organisations that facilitated spending time together and integrating society into commercialised enterprises. These changes are the most visible in the case of the best clubs from the so-called Big FiveSpain, Germany, Italy, France, and England-which have already become global brands and have fans all over the world. Therefore, the clubs are expected not only to achieve their goals for the sport, but also to reach specific economic goals depending both on their ranking and their budget. In addition, football clubs are perceived as organisations that not only serve as a source of entertainment but are also capable of promoting specific values and pursuing several social goals to improve the quality of life of local communities (Kuźbik, 2016, p. 120). Social responsibility is especially important for clubs with a global reach, as millions of people $^{1}$ observe not only their fight for world trophies, but are also interested in their non-sports activities, and the players are role models for many of their fans. This article will present FC Barcelona's activities in the field of social responsibility and an analysis of these activities in the context of the CSR pyramid proposed by A. B. Carroll.

\section{Corporate social responsibility}

According to Grzegorz Zasuwa (2012), CSR in the new paradigm, is treated as an investment to bring specific benefits. It can contribute to achieving a company's competitive advantage if new products or innovative business processes are created as a result of social involvement (p. 187). Positive effects of CSR include: the promotion of sustainable development, the improvement of health and well-being of society, an increased interest on the part of investors, the improvement of relations with the local community and authorities, growth of customer loyalty, the creation of a positive image of a company or the attracting of talented employees (Skrzypek, 2015, p. 202). In addition, expectations of society towards enterprises are constantly changing. Apart from the standard offer of high-quality products or services, companies are expected to respect the needs of stakeholders and minimise a negative impact on society or the natural environment. An organisation that does not meet these requirements may not survive in the market, as the disclosure of irresponsible behaviour usually results in a loss of customers and a dramatic drop in sales (Filizöz \& Fisneb, 2011, p. 1406). It is not surprising that today's enterprises are increasingly trying to be socially responsible, and the CSR concept itself is a subject of great interest to not only entrepreneurs but also international organisations (Carroll, 1979, p. 500). Subject matter experts do not agree on the

\footnotetext{
${ }^{1}$ As reported in the 2016/2017 season report, FC Barcelona has 293,000,000 fans on social media, an impressive number, even if some of them have also accounts on different platforms.
} 
definition of corporate social responsibility or its components, which is why many researchers are considering the essence of this concept (Carroll, 1999, pp. 268295; Hamidu, Haron \& Amran, 2015, pp. 83-95; Kuźbik, 2016, pp. 69-100; Sheehy, 2015, pp. 625-648).

For this article, the author will rely on the approach to CSR proposed by A. B. Carroll (1979). His early CSR definition states:

The social responsibility of business encompasses the economic, legal, ethical and discretionary expectations that society has of organisations at a given point in time. (p. 500)

In 1991, Carroll finetuned it by proposing that the CSR consisted of four dimensions: economic, legal, ethical and philanthropic. These are presented in the form of a pyramid (Fig. 1). He added that all the components had always been included in the concept of CSR only that ethics and philanthropy had gained in importance in recent times (Carroll, 1991, p. 40). According to Carroll, a CSR driven company "should strive to make a profit, obey the law, engage in ethical practices and be a good corporate citizen" (p. 43).

It is not without good reason that Carroll in the first place in his model mentions economic responsibility that is required by a society. The rational allocation of financial resources is crucial for the existence of a company, which in certain circumstances will provide the company with a profit, as well as financial liquidity along with the company's responsibility for liabilities incurred and proper management of assets (Komorowski, 2011, p. 170). Achieving profit is necessary for a company's survival and its development. These are essential elements in building credibility and trust on which the investors make their decisions. The economic profitability might be included to CSR as the fundamental condition for existence of any enterprise because the society expects a company to be able to secure its development by balancing risks and anticipated benefits (Carroll, 2016, p. 3; Komorowski, 2011, p. 171)

According to Carroll, the second area of social responsibility is the legal aspect. In its actions, a company should comply with all applicable laws-local, national and international, including a respect for human rights (Jutterström \& Norber, 2013, p. 5). The legal responsibility dictates: offering products and services that meet at least the minimum legal requirements, fulfilling legal obligations towards stakeholders, and being a law-abiding corporate citizen (Carroll, 2016, p. 3).

The other two dimensions of social responsibility in Carroll's pyramid: ethical and philanthropic one, are not required by law but are the result of voluntary decisions and actions. For each organisation legal and financial responsibility are the minimum but for those who aim to develop and gain competitive advantage this minimum has to be supplemented with moral responsibility as first two dimensions are no longer sufficient (Kuźbik, 2016, pp. 57-58). That is why Carroll adds ethical responsibility, third — not required but expected by a society-aspect of CSR (Carroll, 1999, p. 283) Many companies define the ethical framework of activities that they conduct to accomplish their mission. This framework often 
contains a list of key values and their definitions (Snider, Hill \& Martin, 2003, p. 180) that companies use when making decisions and solving emerging problems. It is expressed through the formalisation of moral norms in the form of ethical codes or sets of good practices, as well as through the organisation of ethics training and monitoring systems or, simply, by the enforcement of accepted norms. The confirmation of moral responsibility of an organisation is provided by means of formal certification and voluntarily announced social reports to communicate these activities to the stakeholders (Lewicka-Strzałecka, 2006, p. 78).

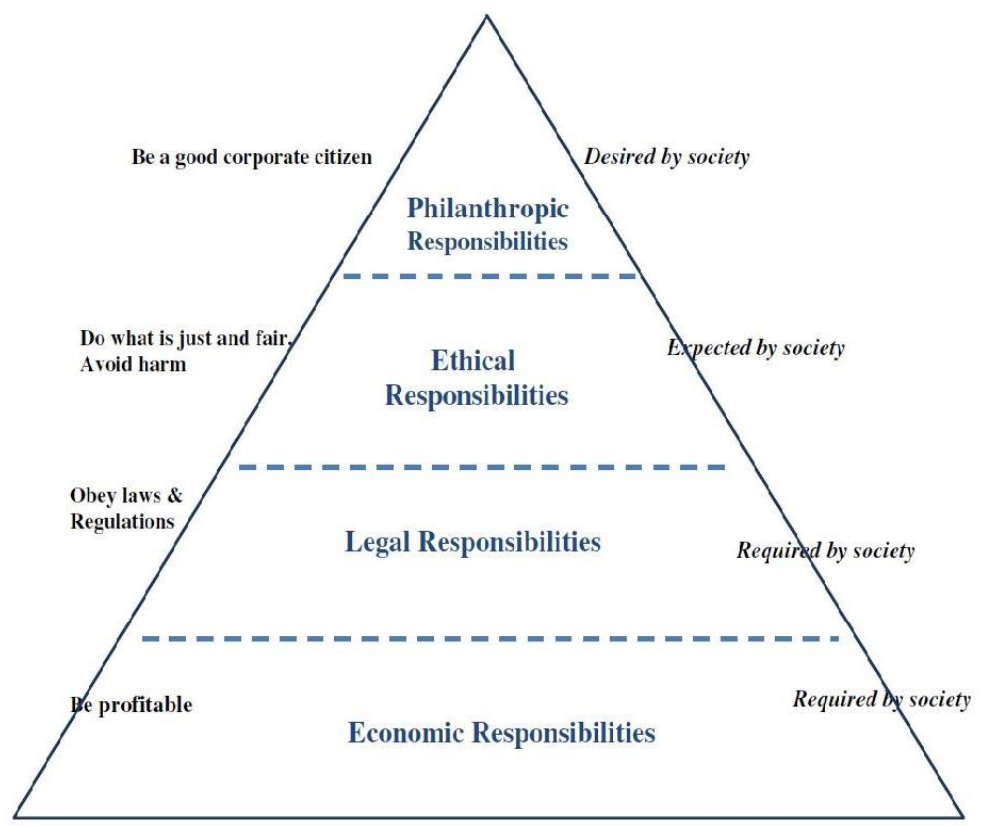

Fig. 1. Carroll's Pyramid of CSR

Note. Adapted from "Carroll's pyramid of CSR: taking another look," by A. B. Carroll, 2016, International Journal of Corporate Social Responsibility, 1(3), p. 5.

The fourth element of Carroll's pyramid is philanthropy, including financial support for the needy individuals or groups, and various forms of volunteering in which employees can use their skills and abilities outside the organisation. Philanthropic activities are often carried out through charitable funds to accomplish various social goals financed by companies (Haynes, Murray \& Dillard, 2013, p. 231). In Carroll's pyramid, philanthropy is not required by the society, meaning that if a company does not engage in such activities it will not be seen as organisation which violates CSR rules. It is, however, desired by society and per- 
ceived as one of the manifestations of being a good corporate citizen (Carroll, 2016, p. 4).

\section{FC Barcelona as a socially responsible organisation}

FC Barcelona has been a world-class club for many years. It regularly participates in the Champions League games and has been a 5-times victor. It has won 22 international tournaments, 23 in the Spanish league, 28 in the King's Cup (Copa del Rey) and several others. As one of the three Spanish teams, it has never fallen out of the Primera Division. It has millions of fans around the world making FC Barcelona a global brand.

The club dates back to 1899 when Hans Gamper, a Swiss, gathered a group of 12 male football players in Catalonia and founded an association: Football Club Barcelona (Fútbol Club Barcelona). Even then, the distinctive features of the club were forming: Catalan identity, democracy, multiple sports and universality. ${ }^{2}$ More than one hundred years later, on its official website, one finds the very similar characteristics of FC Barcelona: Catalanism, universality, and democracy. However, the fourth value has changed - social commitment has replaced multiple sports. ${ }^{3}$ This change indicates that social responsibility has become one of the pillars of FC Barcelona's activity. Through its CSR activities, the "Catalan Pride" shows that the motto "More than a club" is not just a slogan but a commitment to the local and global community.

Due to the specific nature of activities of the football clubs, the CSR initiatives will differ depending on the stakeholders and the interests and initiatives. The internal stakeholders of a sports club include all its employees (players, sports and medical staff, administrative employees), owners, shareholders, investors and trade unions. External stakeholders include customers, competitors, creditors, suppliers (e.g.: companies providing equipment for footballers), TV stations, local and international sports institutions, local and national authorities, the local community (Filizöz \& Fisneb, 2011, p. 1410; Skrzypek, 2015, p. 194), universities, media, courts and other entities constituting the organisation's environment (Sznajder, 2013, p. 197), and - as the so-called silent stakeholder (Jastrzębska, 2015, pp. 49-51) - the natural environment.

In FC Barcelona, a participatory democracy model is used, combining membership with club ownership, which is why one of the most important stakeholder groups are club members known as socios. They are part of the council of delegates and have a real influence on club management. They have the right to choose the club's president and board as well as to verify whether decisions taken by the board are in accordance with the applicable statute, they also have the right to vote on charitable activities of the FC Barcelona Foundation (Hamil, Walters $\&$ Watson, 2011, p. 154). As of June 30, 2017, the socios group comprises

\footnotetext{
${ }^{2}$ https://www.fcbarcelona.com/club/history/decade-by-decade

${ }^{3}$ https://www.fcbarcelona.com/club/identity/card/more-than-a-club
} 
143,855 members, of whom as many as 132,748 live in Catalonia. Men dominate among club members (74\%), women constitute $26 \%$ of the population. The statistics do not distinguish children, but almost 9,000 members are persons under 5 years of age (FC Barcelona, Report 2016/2017 [hereinafter referred to as Report 2016/2017], p. 110). One can see that being socio of FC Barcelona is in many cases a family tradition and proof of a true membership in the club.

FC Barcelona's activities in the field of corporate social responsibility in the framework of a system corresponding to Carroll's CSR pyramid are presented below. It should be emphasised that this division is conventional, as individual activities can often be qualified to more than one dimension. The main entity enabling ethical and philanthropic activities on behalf of FC Barcelona is the Barca Foundation established in 1994, thanks to which over one million children around the world have already received assistance in the framework of a variety of programmes.

\subsection{Financial aspect}

Although matches and accompanying emotions are the main product offered by football clubs, one must not forget that in the commercialised world a club is an enterprise that must look after its profitability (cf. Kuźbik, 2016, p. 117). The proceeds from match tickets do not ensure stable development for clubs, which is why, especially in the case of global clubs, an increasing share of revenues comes from business activities. Specially designed stadiums are aimed at attracting fansconsumers to the shopping centres operating on their premises "in which (almost) all consumer needs can be met" (Antonowicz, Kossakowski \& Szlendak, 2015, p. 119). A club's income consists of revenues from tickets and rights to broadcast matches, revenues from transfers, money obtained from sponsors and from trade in goods. Expenses are mainly the costs of transfers and players' remuneration.

Each club participating in tournaments organised by the UEFA which achieves income or incurs expenses over $€ 5$ million is required to comply with the rules of financial fair play (Tittenbrun, 2016, p. 88). These have been specified and codified by the UEFA in relevant documents. Any violation of these rules may result in penalties - ranging from a reprimand to exclusion from matches or taking back a won trophy. The main financial requirements of the UEFA (2015) are: no overdue payments to football clubs (timely payment of fees for player transfers), a lack of arrears in the players' remuneration and payments resulting from rights to use their image, bonuses and other contractual benefits, and a lack of tax arrears (pp. 26-31). The condition for the UEFA's positive assessment of a club is the presentation of the required financial documents and the balance between expenses and revenues in the three-year settlement period (Tittenbrun, 2016, p. 88). An additional audit can be made if the salaries and bonus expenses for employees exceed $70 \%$ or the net debt exceeds $100 \%$ of the annual income (UEFA, 2015, p. 39). The financial report for the financial year 2016/2017 shows that FC Barcelona generated an operating profit of 708,169 thousand Euros, which is a $4 \%$ increase from the year before. An examination of the club's revenues for 
the previous five seasons shows that they have been systematically growing, which leads to the conclusion that the club manages its finances rationally. What is more, the players' salaries remain below the $70 \%$ recommended by the UEFA, and the debt ratio within the standards set in the Club's By-Laws (Report 2016/2017, pp. 290-291).

As part of the social responsibility strategy, the club should support the training of children and young people as well as activities aimed at developing the local community. It is worth noting that expenditures on women's football and infrastructure development are excluded from the break-even analysis - a basic indicator of financial fair play (Schubert, Könecke \& Pitthan, 2016, p. 299). FC Barcelona is actively engaged in the development of children and young adults. The most famous forge of young talents is, of course, La Masia, which has trained players as Lionel Messi, Andrés Iniesta and Jordi Alba and many others. Although adepts of this youth academy get their chance less often than in the past, the example of Sergi Roberto, who joined the first team in 2013 indicate that La Masia still train players who are vital part of FC Barcelona's success. Additionally, the club runs 36 football academies on five continents. The Warsaw FCB Escola Varsovia where children between the ages of 6 and 12 are trained in the sport and the philosophy of FC Barcelona is one such school. ${ }^{4}$ Young students of football schools meet at tournaments organised by the club. In the 2016/2017 season alone, more than 1,500 children from 20 countries participated in the FCB Escola International Tournament. The club organised over 170 training camps, including the first girls camp in Iceland (Report 2016/2017, p. 190).

\subsection{Legal aspect}

Each football club must meet a number of legal requirements if it wants to participate in both national league and international championships. The higher the level of tournaments, the more demanding and detailed the regulations that govern them are. FC Barcelona takes part in La Liga Santander, Copa del Rey, and the Catalan Cup, and has been continuously playing in the Champions League for many seasons. Each of these tournaments has its own rules which the club must adapt to not be excluded from it. ${ }^{5}$ La Liga is one of the three European leagues with the highest UEFA index. This position entitles it and therefore to putting up three teams in the Champions League, and the fourth in the qualifying rounds. Two successive teams from La Liga and the cup winner are eligible for the Europa League. Football clubs participating in international championships must also comply with the financial fair play rules mentioned earlier.

\footnotetext{
${ }^{4}$ https://www.fcbescola.pl

${ }^{5}$ The rules of qualification and participation in individual tournaments are very detailed and strictly determined by the appropriate sports body. A number of regulations relating to La Liga can be found on the site: http://www.laliga.es/lfp/normativa. Champions League matches are regulated by the UEFA, which publishes a special document for each season, e.g.: UEFA (2017a). The rules of the Europa League are defined by the same body in the document: UEFA (2017b).
} 
The examples of the adjustment of FC Barcelona's activities to new legal regulations at the end of the 2015/2016 season listed in the report indicate the degree of meticulousness and thoroughness of the requirements in relation to clubs. These included: the improvement of lighting at Camp Nou, new camera positions on the pitch, the improvement of shelters, the press box and zones for the directors of the match, and the introduction of new match documents (Report 2016/2017). Due to a large number of rules and regulations, it is impossible to fully analyse their implementation by a specific club, but the presence of FC Barcelona in prestigious tournaments indicates that it meets the legal responsibility criterion. The internal regulations regarding the functioning of the club are included in its regularly updated Statute (FC Barcelona, 2013).

FC Barcelona shows great concern for respect for human rights. In its Code of Ethics, the club's organisational culture has been defined as "firmly based on fulfilment of human and social rights" (FC Barcelona, 2016, p. 6). The Code also contains a statement that FC Barcelona respects human rights recognised internationally, contained, among others, in the Charter of Human Rights and the Declaration of the International Labour Organisation. This results in building relationships between employees based on mutual respect, creating healthy and safe working conditions and avoiding any form of harassment and discrimination (p. 12). The players of the Catalan Pride participate in the UEFA's "No to Racism" campaign, aimed to combat racism, discrimination and intolerance in football.

\subsection{Ethical aspect}

As mentioned in the presentation of Carroll's pyramid, ethical responsibilities are not required by society, but stakeholders expect the club to act ethically. This dimension of social responsibility is particularly important in sport, as many people admire and imitate players' behaviour, looking not only at their sports achievements but also at their values and specific conduct. It is important to build the image of the club and maintain its consistency with all of its activities.

The key values at FC Barcelona are respect, effort, ambition, teamwork and humility. ${ }^{6}$ They are, next to their love for football, a part of the blue-red soul of FC Barcelona (Violan, 2014, p. 53). Barcelona, realising its "More than a club" motto, wants not only to win in style but to provide its fans a spectacle. One factor that enables such a spectacle is Barcelona's specific game philosophy, the TiquiTaca. It is a form of fulfilling the values of the club, as its unique technical skills, quick passes and the pace of the game (Boedker, 2016) require an effort, teamwork and humility. The values shared by the club members are instilled in the players of the young teams playing under the auspices of Barcelona. They are also promoted by sports activities, games or educational stories as part of the Barça kids programme. It is aimed at children between 6 and 12 years of age in Catalonia

\footnotetext{
${ }^{6}$ https://www.fcbarcelona.com/club/identity/card/values
} 
and other places where the Catalan language is spoken (FC Barcelona Foundation, Report 2015/2016 [hereinafter referred to as Report 2015/2016], p. 24).

FC Barcelona has its own Code of Ethics and Conduct adopted in 2010, which applies to all employees of the club, as well as people associated with it. The statement that they are obligated to fulfil all requirements towards third parties resulting from contracts indicates the responsibility of the club towards its stakeholders. In this context, the principles of relations with customers, suppliers, etc. have also been codified. In addition, all activities undertaken by members and persons associated with FC Barcelona should be performed with due diligence, responsibility and professionalism (FC Barcelona, 2016, p. 10). Club authorities, ensure that the services offered meet not only the minimum required standards but are of high quality and professionally rendered.

The Code includes regulations on equal access to tools enabling employees their professional development, clear criteria of promotion, as well as the guarantee of ensuring a work-life balance, which proves responsibility towards employees, i.e. internal stakeholders of the club. The Code also regulates the unauthorised expenses and benefits, corruption, and sports betting. Additionally, FC Barcelona seeks to comply with all the applicable tax laws and report on all its activities in this area (FC Barcelona, 2016, p. 15).

Programmes addressed to the children who are struggling with serious diseases are also part of activities conducted by the foundation run by FC Barcelona. "The Project Hope" and "The Hospitals Project" are programmes in which the children can meet with players from the first team and club activists. During the Christmas season, the players visited over 1,000 children in hospitals in and around Barcelona. In addition, more than 100 children were invited to matches or training sessions during which private meetings with players took place. ${ }^{7}$ Thus, the world's top players, by devoting their time, bring the children enormous joy and contribute to their dreams.

\subsection{Philanthropy}

Philanthropic activity is often treated as an element of public relations, however, in a large part of socially responsible organisations, it flows from the adopted strategy rooted in shared values and genuine willingness to help the local community (Haynes, Murray \& Dillard, 2013, p. 231). In the case of FC Barcelona, its recognition is so enormous that the club does not need to use philanthropy to improve its image, which is why this activity can be perceived as an expression of concern and striving for social change. One of the examples of philanthropic activity is the cooperation of FC Barcelona with the UNICEF, in which the players of the club spent five years playing in shirts with the UNICEF logo, thus giving up the possibility of obtaining any sponsorships. The initiative was a sensation in the football world, as instead of signing a lucrative contract, FC Barcelona contributed to raising the visibility of UNICEF and its activities. On the $10^{\text {th }}$ anniversary of the

\footnotetext{
${ }^{7}$ https://foundation.fcbarcelona.com/progpedwellbeing
} 
cooperation, the organisations signed a new contract under which FC Barcelona was to provide $\$ 2$ million annually for the children. As a result, children from Brazil, China, Ghana and South Africa have access to education and sport. In addition, this cooperation helps to fight for respecting children's rights and raising awareness about AIDS in Angola, Malawi and Swaziland. ${ }^{8}$

An example of philanthropic activity can also be found in the FootballNet programme implemented by the FC Barcelona Foundation, addressed to people between 8 and 21 years of age. Its aim is to promote specific values by organising various events and engaging the children in cooperation with local organisations based on the vulnerability criterion (Report 2015/2016, p. 14). In the 2015/2016 season, the guiding value in FootballNet was social exclusion, therefore a number of activities were undertaken to allow people with disabilities to take part in the programme and show they could participate in sports activities (p. 17). Thanks to the cooperation with Shell, FootballNet is now present in Iraq, Oman, Qatar and Saudi Arabia, involving local staff especially trained for this purpose. In these countries, it has been particularly important to include girls in the programme and provide them with access to training in appropriate conditions (pp. 19-20). The Barca Foundation has also covered with its programme over 4,000 of young refugees from camps in Greece, Italy and the Middle East. ${ }^{9}$ All the presented activities effectively combat exclusion in various aspects of social life.

The FC Barcelona Foundation supports financially the construction of SCJ Paediatric Oncologic Centre in Barcelona to enable more effective treatments against cancer among children. Fulfilling the dreams of sick children, employees of the club send them shirts signed by the players and other gadgets from the club shop. As mentioned earlier, the first team players visit children on the occasion of Christmas or New Year and invite them to matches and training sessions. ${ }^{10}$

\section{Conclusions}

The aim of the article was to present FC Barcelona's activities in the field of CSR as the implementation of Carroll's CSR pyramid in practice.

In financial terms, the most important thing for a football club is to comply with the UEFA's financial fair play rules, which in this case are dutifully executed. FC Barcelona has systematically increased its operating profit for past five seasons. The presence of the club in domestic and international tournaments indicates that it meets all the legal requirements imposed by the international bodies managing these events. Hence, the criterion of legal responsibility is systematically implemented.

FC Barcelona, with the participation of the foundation set up by the club, realises several programmes that demonstrate the ethical and philanthropic respon-

\footnotetext{
${ }^{8} \mathrm{https}: / /$ www.unicef.org/media/media_90305.html

${ }^{9}$ https://foundation.fcbarcelona.com/refugeeProg.

${ }^{10} \mathrm{https}$ ///foundation.fcbarcelona.com/progpedwellbeing
} 
sibility of the club. In its activities, FC Barcelona is guided by well-defined key values that are shared and promoted not only among players and members, but also among the children and youth adults on different continents. The club's employees and associates are bound by the Code of Ethics and Conduct that regulates various aspects of FC Barcelona's activities, including contacts with particular stakeholder groups.

The examples of actions taken are a sufficient proof that the club conducts activities in every dimension of social responsibility distinguished in Carroll's pyramid, in terms of the financial and legal aspects required by society as well as in the ethical and philanthropic dimensions perceived as voluntary. Therefore, FC Barcelona can be seen as a socially responsible organisation that meets expectations of its stakeholders.

\section{References}

Antonowicz, D., Kossakowski, R., \& Szlendak, T. (2015). Aborygeni i konsumenci. O kibicowskiej wspólnocie, komercjalizacji futbolu i stadionowym apartheidzie. Warsaw: Wydawnictwo Instytutu Filozofii i Socjologii Polskiej Akademii Nauk.

Boedker, B. (2016). The legendary ten. From humble beginnings to big business. Pennsauken: BookBaby.

Carroll, A. B. (1979). A three-dimensional conceptual model of corporate social performance. Academy of Management Review, 4(4), 497-505.

Carroll, A. B. (1991). The pyramid of corporate social responsibility: Toward the moral management of organisational stakeholders. Business Horizon, 34(4), 39-48.

Carroll, A. B. (1999). Corporate social responsibility. Evolution of a definitional construct. Business and Society, 38(3), 268-295.

Carroll, A. B. (2016). Carroll's pyramid of CSR: taking another look. International Journal of Corporate Social Responsibility, 1(3).

European Commission. (2011, October 25). Communication from the Commission to the European Parliament, the Council, the European Economic and Social Committee and the Committee of the Regions. A renewed EU strategy 2011-14 for Corporate Social Responsibility. Brussels.

FC Barcelona. (2013, October 5). Statutes 5.10.2013. https://www.fcbarcelona.com/docu ments/20197/22189896/02755-Llibret-ReformaEstatuts-ENG-Web-OK.v141898 5814.pdf/0cd42db0-f4d7-4465-81ba-e1fccfada8b1

FC Barcelona. (2016). FC Barcelona and FC Barcelona Foundation Code of Ethics and Conduct. https://pro-cdn-public-fcb.everincloud.com/20157/43501761/656469/1. 0/656469.pdf? $\mathrm{t}=1490701026000$

FC Barcelona Foundation. (2016). Report 2015/2016.

FC Barcelona. (2017). Report 2016/2017.

Filizöz, B., \& Fisneb, M. (2011). Corporate social responsibility: A study of striking corporate social responsibility practices in sport management. Procedia Social and Behavioral Sciences, 24, 1405-1417. doi:10.1016/j.sbspro.2011.09.062 
Hamidu, A. A., Haron, H., \& Amran, A. (2015). Corporate social responsibility: A review on definitions, core characteristics and theoretical perspectives. Mediterranean Journal of Social Sciences, 6(4), 83-95. doi:10.5901/mjss. 2015.v6n4p83

Hamil, S., Walters, G., \& Watson, L. (2011). The model of governance at FC Barcelona: balancing member democracy, commercial strategy, corporate social responsibility and sport performance. In D. Hassan, \& S. Hamil (Eds.), Who owns football?: Models of football governance and management of the club game worldwide (pp. 133-162). New York: Routledge.

Haynes, K., Murray, A., \& Dillard, J. (2013). Corporate social responsibility: A research handbook. New York: Routledge.

Jastrzębska, E. (2015). Środowisko przyrodnicze jako niemy interesariusz społecznie odpowiedzialnego przedsiębiorstwa. Dobre praktyki biznesu w Polsce. Logistyka Odzysku, 2(15), 49-51.

Jutterström, M., \& Norber, P. (2013). CSR as a management idea. In M. Jutterström, \& P. Norber (Eds.), CSR as a management idea. Ethics in action. Cheltenham: Edward Elgar Publishing.

Komorowski, J. (2011). Cele i wartości wspótczesnego przedsiębiorstwa. Ujęcie behawioralne. Warszawa: Oficyna Wydawnicza SGH.

Kuźbik, P. (2016). Społeczna odpowiedzialność w przestrzeni organizacyjnej klubu piłkarskiego. Lodz: Wydawnictwo SIZ.

Lewicka-Strzałecka, A. (2006). Odpowiedzialność moralna $w$ życiu gospodarczym. Warszawa: Wydawnictwo Instytutu Filozofii i Socjologii Polskiej Akademii Nauk.

Schubert, M., Könecke, T., \& Pitthan, H. (2016). The guardians of European football: UEFA Financial Fair Play and the career of social problems. European Journal for Sport and Society, 13(4), 296-324.

Sheehy, B. (2015). Defining CSR: Problems and solutions. Journal of Business Ethics, 131, 625-648.

Skrzypek, A. (2015). CSR jako element strategii organizacji. Prace Naukowe Uniwersytetu Ekonomicznego we Wrocławiu. Zrównoważony rozwój organizacji - aspekty spoteczne, 378, 192-205.

Snider, J., Hill, R. P., \& Martin, D. (2003). Corporate social responsibility in the $21^{\text {st }}$ century: A view from the world's most successful firms. Journal of Business Ethics, 48, $175-187$.

Sznajder, M. (2013). Korzyści z wdrożenia koncepcji społecznej odpowiedzialności biznesu (z uwzględnieniem koncepcji interesariuszy). Economics and Mangement, 2, 194-211.

Tittenbrun, J. (2016). Pieniądz kręci piłka. Stosunki ekonomiczno-własnościowe w futbolu. Warszawa: Wydawnictwo Naukowe PWN.

UEFA. (2015). UEFA Club Licensing and Financial Fair Play Regulations. Edition 2015.

UEFA. (2017a). Regulations of the UEFA Champions League; 2015-18 Cycle; 2017/18

Season. https://www.uefa.com/MultimediaFiles/Download/Regulations/uefaorg/ Regulations/02/46/71/38/2467138_DOWNLOAD.pdf

UEFA. (2017b). Regulations of the UEFA Europa League; 2015-18 Cycle; 2017/18 Season. https://www.uefa.com/MultimediaFiles/Download/Regulations/uefaorg/Re gulations/02/46/71/42/2467142_DOWNLOAD.pdf 
Violan, M. A. (2014). Pep Guardiola. The philosophy that changed the game. UK: Meyer\&Meyer Sport Ltd.

Zasuwa, G. (2012). Społeczna odpowiedzialność jako perspektywiczny obszar sprawozdawczości przedsiębiorstw. In D. Mikulska (Ed.), Polityka rachunkowości jednostki a jakość sprawozdania finansowego. Wybrane aspekty (pp. 185-200). Lublin: Katolicki Uniwersytet Lubelski.

https://foundation.fcbarcelona.com/refugeeProg

https://www.fcbarcelona.com/club/history/decade-by-decade

https://www.fcbarcelona.com/club/identity/card/more-than-a-club-

https://www.fcbescola.pl

https://www.unicef.org/media/media_90305.html

https://foundation.fcbarcelona.com/progpedwellbeing 